\title{
Copper stress affect seed germination and seedling establishment of Schinus terebinthifolia Raddi
}

\author{
(D) Matheus Casarini Siqueira ${ }^{1,4}$, id Armando Reis Tavares ${ }^{3}$, (iD José Marcos Barbosa ${ }^{2}$ \\ and iD Nelson Augusto dos Santos Junior ${ }^{2}$
}

Received: 13.05 .2020 ; accepted: 30.07 .2020

How to cite: Siqueira, M.C., Tavares, A.R., Barbosa, J.M., \& Santos Junior, N.A. 2020. Copper stress affect seed germination and seedling establishment of Schinus terebinthifolia Raddi. Hoehnea 47: e502020. http://dx.doi.org/10.1590/2236-8906-50/2020

\begin{abstract}
Copper stress affect seed germination and seedling establishment of Schinus terebinthifolia Raddi). Pollution by the discharge of copper in the environment due to anthropogenic, industrial, and automobile activities is an environmental problem. Copper is also widely used in different forms as fertilizers and fungicides. Here, we aimed to evaluate seed germination and the establishment of Schinus terebinthifolia Raddi, popularly known as 'Brazilian pepper tree' seedlings submitted to different concentrations of copper. Five treatments were used, with four replicates and 20 seeds per replicate, totaling 400 seeds. $\mathrm{Cu}\left(\mathrm{CuSO}_{4} .5 \mathrm{H}_{2} \mathrm{O}\right)$ was added to the substrate at doses of $0 ; 60 ; 760 ; 2,100$ or $10,000 \mathrm{mg} \mathrm{kg}^{-1}$. The variables percentage, speed, and mean germination time, as well as establishment of seedlings, were analyzed. Cu doses of 2,100 or $10,000 \mathrm{mg} \mathrm{kg}^{-1}$ inhibited seedling formation. $\mathrm{Cu}$ concentration of $10,000 \mathrm{mg} \mathrm{kg}^{-1}$ reduced the final values of germination and speed germination to about one third of those obtained in the control treatment. Compared to germination, establishment of seedlings was more affected by excess copper for the S. terebinthifolia. The species tolerated doses up to $760 \mathrm{mg} \mathrm{kg}^{-1}$ copper during seedling establishment, which indicates that it is a candidate for environmental restoration programs for soils with known copper contamination.
\end{abstract}

Keywords: brazilian pepper tree, heavy metal, phytotoxicity, plant stress, seedling growth

RESUMO - (O estresse por cobre afeta a germinação de sementes e o estabelecimento de plântulas de Schinus terebinthifolia Raddi). A poluição de cobre no meio ambiente, devido a atividades antropogênicas, industriais e automotivas é uma preocupação ambiental. O cobre é amplamente utilizado em diferentes formas como fertilizantes e fungicidas. Ainda são poucos os estudos que descrevem o efeito do cobre na germinação de sementes de espécies tropicais. Neste trabalho, objetivamos avaliar a germinação de sementes e o estabelecimento de mudas de Schinus terebinthifolia Raddi, popularmente conhecido como 'pimenta brasileira', submetidas a diferentes concentrações de cobre. Foram utilizados cinco tratamentos, com quatro repetições e 20 sementes por repetição, totalizando 400 sementes. Foi adicionado $\mathrm{Cu}\left(\mathrm{CuSO}_{4} .5 \mathrm{H}_{2} \mathrm{O}\right)$ ao substrato nas doses de $0,60,760,2.100$ ou $10.000 \mathrm{mg} \mathrm{kg}^{-1}$. Foram analisadas as variáveis porcentagem, velocidade e tempo médio de germinação, bem como estabelecimento de mudas. Doses de $\mathrm{Cu}$ de 2,100 ou $10,000 \mathrm{mg} \mathrm{kg}^{-1}$ inibiram a formação de plântulas. A concentração de $\mathrm{Cu}$ de $10,000 \mathrm{mg} \mathrm{kg}^{-1}$ reduziu os valores finais de germinação e velocidade da germinação para cerca de um terço daqueles obtidos no tratamento controle. Comparado à germinação, o estabelecimento de mudas foi mais afetado pelo excesso de cobre para S. terebinthifolia. A espécie tolerou doses de até $760 \mathrm{mg} \mathrm{kg}^{-1}$ de cobre durante o estabelecimento de plântulas, o que indica que apresenta potencial para ser utilizada em programas de restauração ambiental de solos contaminados por cobre.

Palavras-chave: aroeira, crescimento de mudas, estresse em plantas, fitotoxidade, metal pesado

1. Instituto de Botânica, Núcleo de Pesquisa em Plantas Ornamentais, Av. Miguel Stéfano 3687, 04301-902 - São Paulo, SP, Brasil

2. Instituto de Botânica, Núcleo de Pesquisa em Sementes, Av. Miguel Stéfano 3687, 04301-902 - São Paulo, SP, Brasil

3. Instituto Agronômico, Centro Avançado de Pesquisa Tecnológica do Agronegócio de Frutas, Av. Luiz Pereira dos Santos $1500,13214-$ 820 - Jundiaí, SP, Brasil

4. Corresponding author: matheus.casarini1@gmail.com 


\section{Introduction}

Copper $(\mathrm{Cu})$ is a redox-active (chemical element which acts in electron transfer reactions) transition metal that occurs naturally in soil in the cuprous $\left(\mathrm{Cu}^{+}\right)$and cupric $\left(\mathrm{Cu}^{2+}\right)$ valence states (Barker \& Pealbeam 2015). Copper is an essential micronutrient for plant productivity and, in appropriate concentrations, participates in diverse physiological processes of plant development. However, despite its essentiality, high concentrations of copper can negatively influence biological activities and cause toxicity (Marques et al. 2018). In natural soils, average copper concentrations are relatively low, but due to human activities such as industrialization/urbanization with emission of pollutants and intensive agriculture, the contamination of the soil with heavy metals have become a global concern and bring issues of great interest for research purposes (Zafar et al. 2019). Not only for plants, excess of copper can become a problem for the entire ecosystem since the element accumulates in tissues and presents risks to food chain safety (Farias et al. 2018). According to the governmental agency responsible for inspecting, controlling, and monitoring polluting activities in São Paulo State, values above $60 \mathrm{mg}$ $\mathrm{kg}^{-1} \mathrm{Cu}$ in soils are considered to be potentially harmful to the environment (CETESB 2016). The presence of high amounts of heavy metals in soils can lead to toxic effects and negative impacts on seed germination and seedling growth (Bezini et al. 2019). The main effects of heavy metals on seed germination are reduction in root length with consequent reduced nutrient uptake, decrease in soluble protein and total sugar concentration, reduction in germination rate and seedling abnormalities from oxidative damage (Sethy \& Ghosh 2013, Zhi et al. 2015). Also, copper in excess interferes with the regulation of essential hormones for seed germination, resulting in a reduction or complete inhibition of germination (Ye et al. 2014).

Schinus terebinthifolia Raddi (Brazilian pepper tree), is a pioneer tree from Anacardiaceae family, native to South America. In Brazil, it occurs from the south to the northeast of the country, present in several forest formations (Lorenzi 2016). The species has medicinal and pharmacological importance owing to its antibacterial, anti-inflammatory and curative properties (Estevão et al. 2017). In addition, S. terebinthifolia is widely employed in environmental restoration programs of degraded areas since its growth is fast, and the seed is dispersed by birds (Lorenzi 2016).

Seed germination occurs under favorable light, temperature and humidity (Guardia \& Lamarca 2013); however, the requirements and adequate quantities of these for seed germination vary from species to species (MelaniaNicoleta \& Micle 2015). In addition, some environmental conditions can also influence in the germinative processes, such as salinity and $\mathrm{pH}$ (Weller et al. 2019). Studies on seed germination and seedling establishment under stress conditions, such as hyper concentration of heavy metals in soils, have become increasingly relevant, considering the impacts caused by human activities in natural environments. In general, although the presence of heavy metals in the environment negatively impacts seed germination and seedling establishment (Seneviratne et al. 2019) germination rates in response to $\mathrm{Cu}$ in the environment may vary according to the species. While for most plants, relatively low concentrations of copper are sufficient to reduce or inhibit germination processes (Solanki \& Dhankhar 2011, Abraham et al. 2013), some species present distinct behavior on germination rate that increase in the presence of this heavy metal (Zhi et al. 2015, Litvin et al. 2020). In addition, most studies that verified the influence of heavy metals on seed germination, focused on species of conventional agricultural use. There are still few studies that focus on the influence of copper on the germination of tropical species. Hence, the objective of the study was to evaluate seed germination and establishment of S. terebinthifolia seedlings submitted to different concentrations of copper in substrate.

\section{Material and Methods}

Seeds of S. terebinthifolia were collected from reddishpink mature fruits (Vitória et al. 2018) of an adult individual located at the Instituto de Botânica (233' $22.8^{\prime}$ 'S, $46^{\circ} 37^{\prime} 30.6^{\prime \prime} \mathrm{W}, 800 \mathrm{~m}$ ) inside the Parque Estadual Fontes do Ipiranga (PEFI), a remaining subtropical forest inserted in the Atlantic Forest Domain, in the southern part of São Paulo City, São Paulo State, Brazil. The ripe fruits were opened, and the pulp was withdrawn under running water. The beneficiated seeds were stored in plastic bags in a refrigerator at $6{ }^{\circ} \mathrm{C}$. The seeds had initial water content and mean percentage of germination $(19 \%$ and $42.5 \%$, respectively) determined, as an initial characterization of the lot, according to Lima Junior (2010). The germination tests were conducted in transparent polypropylene boxes $\left(\right.$ Gerbox $\left.^{\circledR}\right)$ containing medium-density vermiculite $(35 \mathrm{~g})$. The treatments were vermiculite $+0 \mathrm{mg} \mathrm{kg}^{-1}$ copper (Control), vermiculite $+60 \mathrm{mg} \mathrm{kg}^{-1}$ copper, vermiculite $+760 \mathrm{mg} \mathrm{kg}^{-1}$ copper, vermiculite $+2,100 \mathrm{mg} \mathrm{kg}^{-1}$ copper or vermiculite + $10,000 \mathrm{mg} \mathrm{kg}^{-1}$ copper. Copper concentrations $\left(\mathrm{CuSO}_{4} .5 \mathrm{H}_{2} \mathrm{O}\right)$ were based on CETESB (2016) reference values for soils contaminated with heavy metals $\left(60 \mathrm{mg} \mathrm{kg}^{-1} \mathrm{Cu}\right.$ - Prevention value; $760 \mathrm{mg} \mathrm{kg}^{-1} \mathrm{Cu}$ - Agricultural Intervention Value; $2,100 \mathrm{mg} \mathrm{kg}^{-1} \mathrm{Cu}$ - Residential Intervention Value and 10,000 $\mathrm{mg} \mathrm{kg}^{-1} \mathrm{Cu}$ - Industrial Intervention Value). The treatments were conducted in a climatized germination room with $25{ }^{\circ} \mathrm{C}$, continuous white light and $70 \%$ relative humidity. The seeds were irrigated with distilled water whenever necessary. The experiment continued for 45 days, and the variables evaluated were percentage of seed germination (G), germination speed index (GSI) (Maguire 1962), mean germination time (MGT) (Labouriau 1983), and percentage of normal (NS) and abnormal seedlings (AS). The seeds were considered germinated when the radicle exceeded 2 
$\mathrm{mm}$ in length and for the characterization of S. terebinthifolia normal and abnormal seedlings, were adopted the predicted morphological parameters described in the "Regras para Análise de Sementes" (Brasil 2009). The experimental design was completely randomized, consisting of five treatments, four replicates and 20 seeds per replicate, totaling 400 seeds. Data were submitted to analysis of variance (ANOVA), and means were compared by Tukey test $(p \leq$ 0.05), using Sisvar Statistical Software 5.6.

\section{Results and Discussion}

The initial percentage of germination of the $S$. terebinthifolia $(42.5 \%)$ was the same as achieved by Luz et al. (2016) in an experiment with the species. The germination percentage of control treatment was $40 \%$, a value equivalent to the germination test rate. Statistically significant changes were observed in percentage of germination for the treatments (figure $1 \mathrm{a}$ ). The percentage of germinated seeds of the treatment with the highest concentration of copper $\left(10,000 \mathrm{mg} \mathrm{kg}^{-1} \mathrm{Cu}\right)$, was significantly reduced when compared to other treatments, and showed values about one third of the percentage of seeds germinated in the control treatment $\left(0 \mathrm{mg} \mathrm{kg}^{-1} \mathrm{Cu}\right)$. Reduction on seed germination caused by excess of heavy metals could be attributed to a reduce water uptake by seeds due to toxicity and osmotic effects of the solution (Bezini et al. 2019), interferences in cell membrane permeability (Caroli et al. 2020) and changes on reserve mobilization in embryo such as decrease of enzymatic hydrolysis of starch, affecting the supply of sugar to developing embryo (Karmous et al. 2015). Toxicity by copper inhibits the activity of the isoenzymes alpha-amylase and invertase, which are responsible for starch and sucrose degradation in the reserve tissues, respectively, reducing the availability of nutrients for seeds during germination (Mittal et al. 2015).

Statistically significant changes were observed in germination speed index for the treatments (Figure $1 \mathrm{~b}$ ). The $10,000 \mathrm{mg} \mathrm{kg}^{-1} \mathrm{Cu}$ dose (Industrial Intervention Value) reduces GSI, as compared to 0 (control) and $760 \mathrm{mg}$ $\mathrm{kg}^{-1}$ (Agricultural Intervention Value). High concentrations of copper are harmful to most crops, reducing the germination potential and the biometric variables of seedlings (Ashagre et al. 2013). No statistically significant changes were observed for mean germination time in all treatments (figure $1 \mathrm{c}$ ). High copper concentrations $(10,000 \mathrm{mg} \mathrm{kg})$ decreased GSI but did not change MGT, which indicates that although the average time required for maximum seed germination was not affected by copper concentrations, the speed in which the seeds germinated during the analyzed period was reduced. The speed and percentage of germination is a very important consideration for pioneer species, as they used to colonize environments that may have adverse conditions and need a short window of opportunity to germinate and establish themselves (Piovan et al. 2019). The seeds submitted to the highest concentration of copper $\left(10,000 \mathrm{mg} \mathrm{kg}^{-1}\right)$ presented the lowest percentage and germination speed, and remarking that the species is a pioneer tree that may compete in the
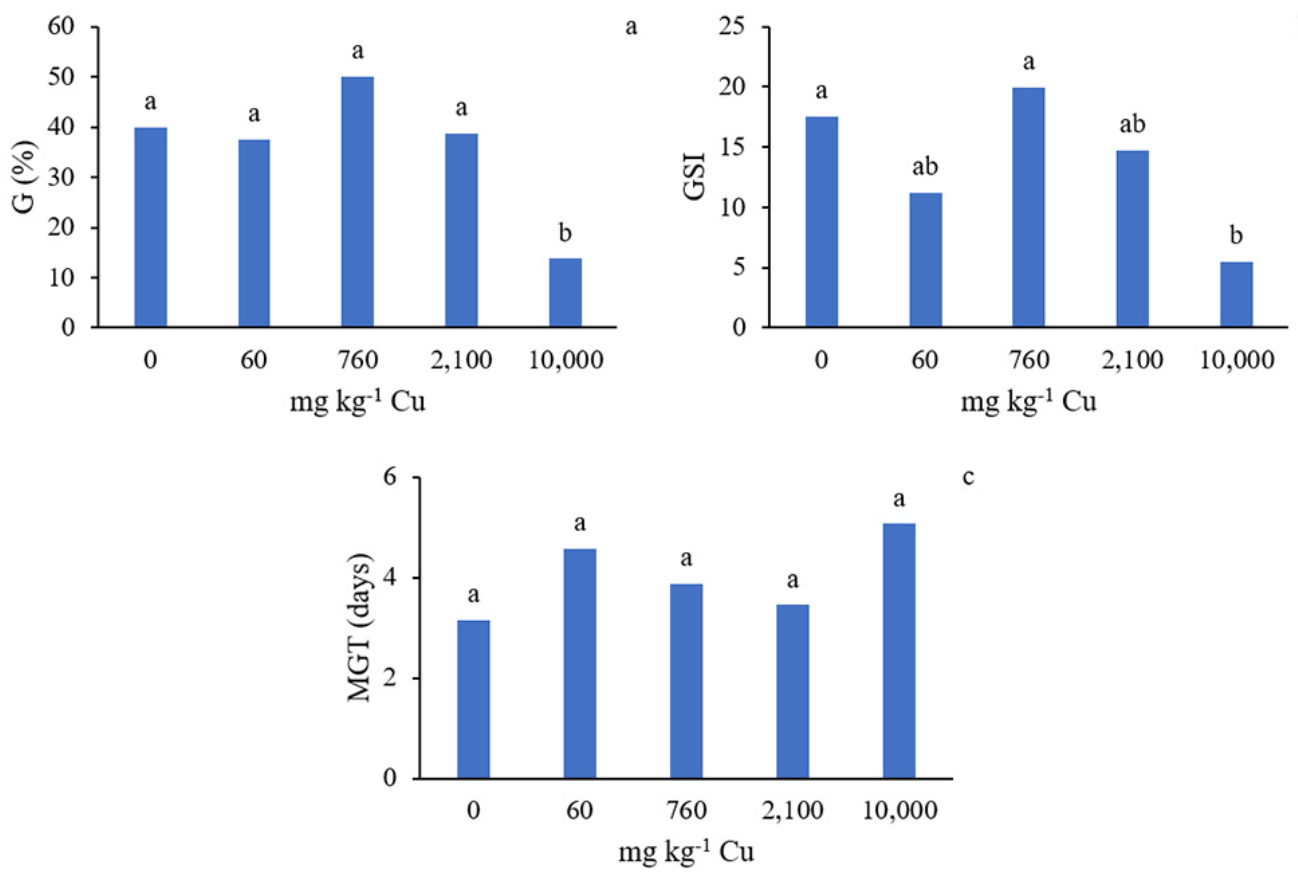

Figure 1. Schinus terebinthifolia Raddi seeds submitted to different concentrations of copper in the substrate. G: Percentage of germination (a); GSI: germination speed index (b); MGT: mean germination time (c). Different letters represent statistical difference by the Tukey test at $5 \%$ probability. 
environment colonization, the effective establishment of this species could be negatively affect in such conditions. However, $760 \mathrm{mg} \mathrm{kg}^{-1} \mathrm{Cu}$, a value considered toxic in soils by CETESB (2016), did not affect any of the variables analyzed for S. terebinthifolia, indicating that this species is tolerant to this concentration. Schinus lentiscifolia, a species of the same genus, has mechanisms of tolerance to heavy metals such as the excretion of ions excess through the leaf surface, after a limit value for the accumulation of salts of these ions in the tissues, and high germination capacity in substrate contaminated by copper (Porto 1989).

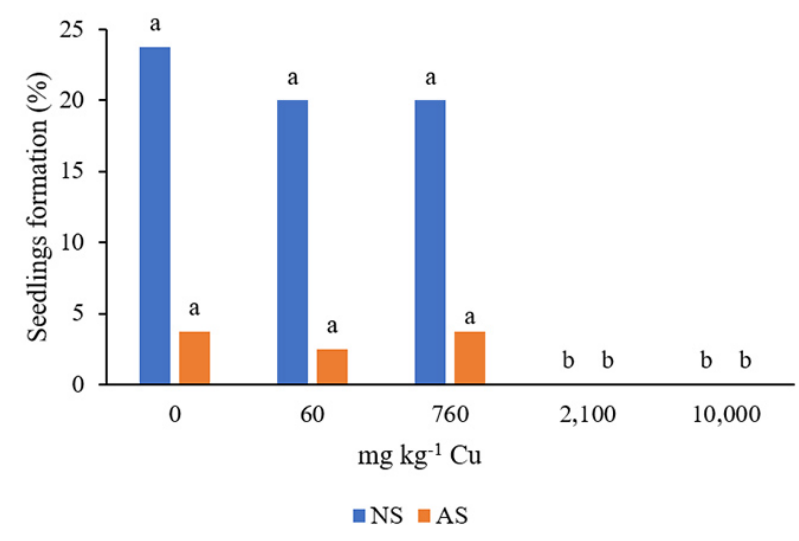

Figure 2. Percentage of Schinus terebinthifolia Raddi normal (NS) and abnormal (AS) seedlings submitted to different concentrations of copper in the substrate, analyzed after 30 days of germination. Different letters represent statistical difference by the Tukey test at 5\% probability.
Schinus terebinthifolia seeds were germinated in all copper concentrations; however, concentrations higher than 2,100 $\mathrm{mg} \mathrm{kg}^{-1} \mathrm{Cu}$ were found to be toxic to the seedlings, producing root necrosis and completely inhibited seedling formation and establishment (figure 2). No statistically significant values were observed in normal (Figure 3 a) and abnormal seedlings (figure $3 \mathrm{~b}$ ) for 0,60 or $760 \mathrm{mg} \mathrm{kg}^{-1}$ $\mathrm{Cu}$ treatments. The abnormal $\mathrm{S}$. terebinthifolia seedlings observed were characterized by the absence or deformity of cotyledons. Seed germination is a process that mostly depends on water availability and the reserve content in seeds, while seedling growth and development is more affected by environmental restrictions (You et al. 2019). In the post-germinative phase, the uptake of elements from the external environment becomes the main source of nutrition for new tissues (Taiz et al. 2017), consequently, changes in nutrient concentrations are reflected more intensely in seedlings. Copper uptake occurs via root system because of its affinity with root cell walls, and the excess inhibits the transcription of cell division-related genes with harmful effects on the root system (Zhu et al. 2017, Ambrosini et al. 2017). The stress caused by excess copper reduces proteolytic activities in the cotyledons, impairing the nutrient mobilization and thus preventing seedlings formation (Karmous et al. 2012). Also, in high amounts copper can be toxic to seedlings, inducing the formation of reactive oxygen species (ROS), mainly hydrogen peroxide $\left(\mathrm{H}_{2} \mathrm{O}_{2}\right)$, which may cause oxidative damage to plant cells (Saleem et al. 2020).

Our results showed that Schinus terebinthifolia seeds germination process is less influenced by copper stress than seedling establishment. The highest copper concentration $\left(10,000 \mathrm{mg} \mathrm{kg}^{-1} \mathrm{Cu}\right)$ there was the greatest reduction in
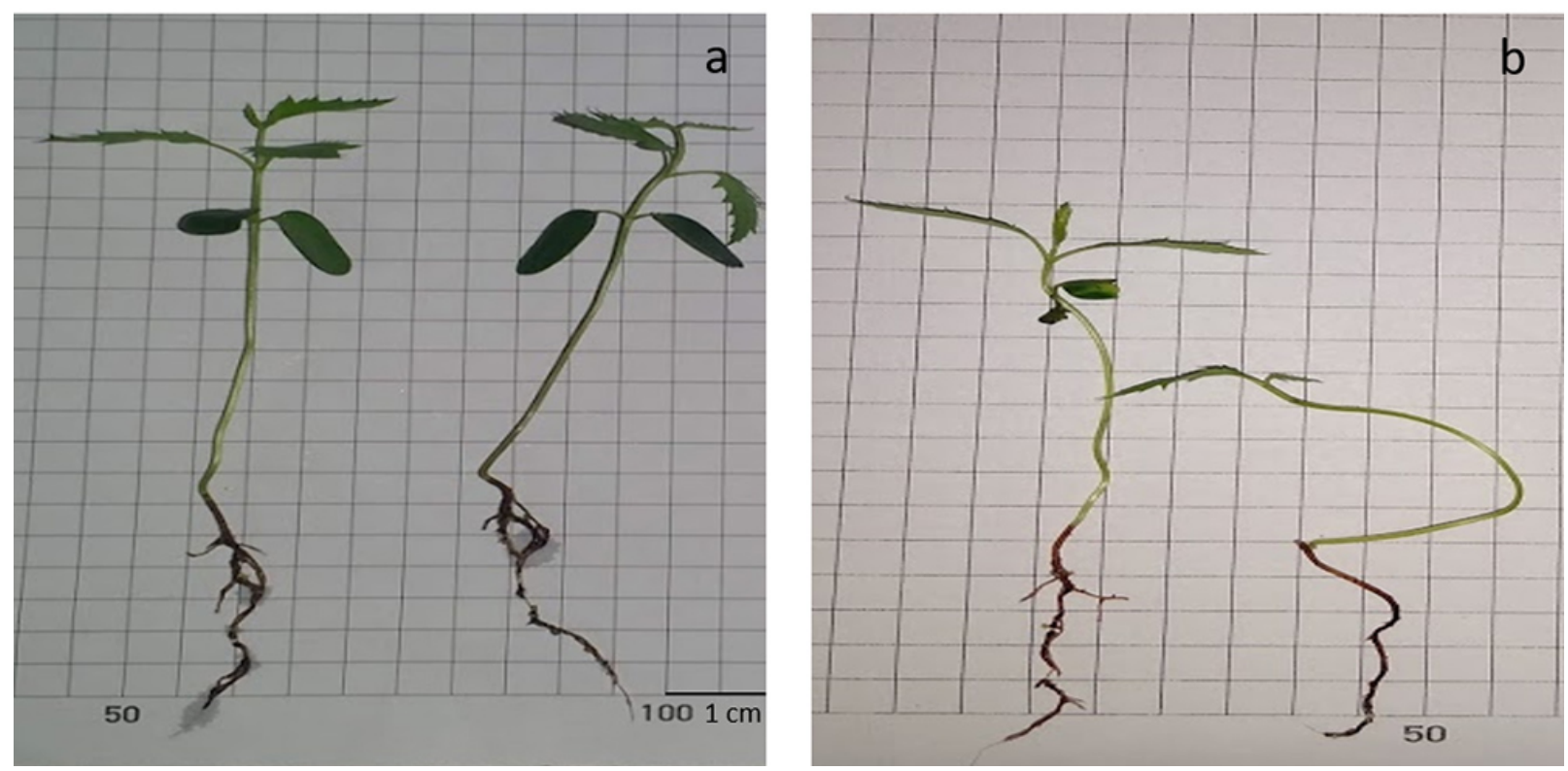

Figure 3. Schinus terebinthifolia Raddi normal (a) and abnormal (b) seedlings, analyzed after 30 days of germination. 
the percentage and speed of germination. The copper concentrations used on our study did not affect the mean germination time of $S$. terebinthifolia seeds. Seedling formation on 2,100 and $10,000 \mathrm{mg} \mathrm{kg}^{-1} \mathrm{Cu}$, did not occur. S. terebinthifolia is tolerant to excess copper within the limits of agricultural intervention $\left(760 \mathrm{mg} \mathrm{kg}^{-1} \mathrm{Cu}\right)$ for seed germination and seedling establishment. The species has characteristics that seem promising for its use in restoration programs of degraded areas by excess copper via direct seeding, mainly as a pioneer species in the beginning of the restauration process.

\section{Acknowledgements}

We thank to Fundação de Amparo à Pesquisa do Estado de São Paulo (FAPESP), for the financial support (2019/03105-4) and M.C.S. master scholarship.

\section{Literature cited}

Abraham, K., Sridevi, R., Suresh, B. \& Damodharam, T. 2013. Effect of heavy metals $(\mathrm{Cd}, \mathrm{Pb}, \mathrm{Cu})$ on seed germination of Arachis hypogeae L. Asian Journal of Plant Science and Research 3: 10-12.

Ambrosini, V.G., Rosa, D. J., Basso, A., Borghezan, M., Pescador, R., Miotto, A., Melo, G.W.B., Soares, C.R.F.S., Comin, J.J. \& Brunetto, G. 2017. Liming as an ameliorator of copper toxicity in black oat (Avena strigosa Schreb.). Journal of Plant Nutrition 40: 404416.

Ashagre, H., Almaw, D. \& Feyisa, T. 2013. Effect of copper and zinc on seed germination, phytotoxicity, tolerance and seedling vigor of tomato (Lycopersicon esculentum L. cultivar Roma VF). International Journal of Agricultural Science Research 2: 312-317.

Barker, A.V. \& Pilbeam, D.J. 2015. Handbook of plant nutrition. 2 ed. CRC press, Boca Raton.

Bezini, E., Abdelguerfi, A., Nedjimi, B., Touati, M., Adli, B. \& Yabrir, B. 2019. Effect of some heavy metals on seed germination of Medicago arborea L. (Fabaceae). Agriculturae Conspectus Scientificus 84: 357-364.

Brasil. Ministério da Agricultura, Pecuária e Abastecimento. Secretaria Nacional de Defesa Agropecuária. 2009. Regras para análise de sementes. ACS, Brasília.

Caroli, M., Furini, A., DalCorso, G., Rojas, M. \& Di Sansebastiano, G.P. 2020. Endomembrane reorganization induced by heavy metals. Plants 9: 482 .

CETESB - Companhia Ambiental do Estado de São Paulo. 2016. Valores orientadores para solo e água subterrânea no estado de São Paulo. Diário Oficial Estado de São Paulo - Caderno Executivo I (Poder Executivo, Seção I), 126 (219): 55-56.
Estevão, L.R.M., Simões, R.S., Cassini-Vieira, P., Canesso, M.C.C., Barcelos, L.S., Rachid, M.A., Câmara, C.A.G. \& Evêncio-Neto, J. 2017. Schinus terebinthifolius Raddi (Aroeira) leaves oil attenuates inflammatory responses in cutaneous wound healing in mice. Acta Cirurgica Brasileira 32: 726-735.

Farias, J.G., Nunes, S.T., Sausen, D., Nunes, M.A., Neis, F.A., Garlet, L.C., Nunes, P.A.A., Dressler, V.L., Schetinger, M.R.C., Rossato, L.V., Girotto, E., Brunetto, G. \& Nicoloso, F.T. 2018. Agricultural contamination: Effect of copper excess on physiological parameters of potato genotypes and food chain security. Journal of Applied Botany and Food Quality 91: 249-259.

Guardia, M.C. \& Lamarca, E.V. 2013. Germinação de sementes de Maclura tinctoria (Moraceae) sob diferentes regimes térmicos influenciados pela luz. Hoehnea 40: 373-380.

Karmous, I., Bellani, L.M., Chaoui, A., El Ferjani, E. \& Muccifora, S. 2015. Effects of copper on reserve mobilization in embryo of Phaseolus vulgaris $L$. Environmental Science and Pollution Research 22: 10159-10165.

Karmous, I., Khadija, J., Chaoui, A. \& EI Ferjani, E. 2012. Proteolytic activities in Phaseolus vulgaris cotyledons under copper stress. Physiology and Molecular Biology of Plants 18: 337-343.

Labouriau, L.G. 1983. A germinação das sementes. Organização dos Estados Americanos. Programa Regional de Desenvolvimento Científico e Tecnológico. Série de Biologia. Monografia 24.

Lima Junior, M.J.V. 2010. Manual de procedimentos para análise de sementes florestais. UFAM, Manaus.

Litvin, V.A., Deriy, S.I., Plakhotniuk, L.N. \& Abi Njoh, R. 2020. Effects of humic substances on seed germination of wheat under the influence of heavy metal. Cherkasy University Bulletin: Biological Sciences Series 1: 42-52.

Lorenzi, H. 2016. Árvores brasileiras: manual de identificação e cultivo de plantas arbóreas nativas do Brasil. 7 ed. Plantarum, Nova Odessa.

Luz, L.V., Mello, E.P., Fernandes, A.P.D., Lencina, K.H. \& Silva, A.C.F. 2016. Evaluation of seed germination of Schinus terebinthifolius Raddi from different matrices on Rio Grande do Sul state, Brazil. Australian Journal of Basic and Applied Sciences 10: 41-48.

Maguire, J.D. 1962. Speed of germination: Aid in selection and evaluation for seedling emergence and vigour. Crop Science 2: 176-177.

Marques, D.M., Júnior, V.V., Silva, A.B., Mantovani, J.R., Magalhães, P.C. \& Souza, T.C. 2018. Copper toxicity on photosynthetic responses and root morphology of Hymenaea courbaril L. (Caesalpinioideae). Water Air Soil Pollution 229: 138. 
Melania-Nicoleta, B. \& Micle, V. 2015. Effects of copperinduced stress on seed germination of maize (Zea mays L.). Agriculture - Science and Practice 3: 95-96.

Mittal, N., Vaid, P. \& Avneet, K. 2015. Effect on amylase activity and growth parameters due to metal toxicity of iron, copper and zinc. Indian Journal of Applied Research 5: 662-664.

Piovan, M.J., Pratolongo, P., Donath, T.W., Loydi, A. \& Eckstein, R.L. 2019. Germination response to osmotic potential, osmotic agents, and temperature of five halophytes occurring along a salinity gradient. International Journal of Plant Sciences 180: 345-355.

Porto, M.L. 1989. Tolerância ao cobre em ecótipos de Schinus lentiscifolius March (Anacardiaceae) de áreas de mineração no Rio Grande do Sul, Brasil. Acta Botanica Brasilica 3: 23-31.

Saleem, M.H., Fahad, S., Khan, S.U., Din, M., Ullah, A., Sabagh, A.E., Hossain, A., Llanes, A. \& Liu, L. 2020. Copper-induced oxidative stress, initiation of antioxidants and phytoremediation potential of flax (Linum usitatissimum L.) seedlings grown under the mixing of two different soils of China. Environmental Science and Pollution Research 27: 5211-5221.

Seneviratne, M., Rajakaruna, N., Rizwan, M., Madawala, H.M.S.P., Ok, Y.S. \& Vithanage, M. 2019. Heavy metal-induced oxidative stress on seed germination and seedling development: a critical review. Environmental Geochemistry and Health 41: 1813-1831.

Sethy, S.K. \& Ghosh, S. 2013. Effect of heavy metals on germination of seeds. Journal of Natural Science, Biology, and Medicine 4: 272.

Solanki, R. \& Dhankhar, R. 2011. Zinc and copper induced changes in physiological characteristics of Vigna mungo (L.). Journal of environmental biology, 32: 747-751.

Taiz, L., Zeiger, E., Møller, I.M. \& Murphy, A. 2017. Fisiologia e desenvolvimento vegetal. 6 ed. Artmed Editora, Porto Alegre.
Vitória, R.Z., Oliveira, F.T.G., Posse, S.C.P., Arantes, S.R., Dousseau, S., Schmildt, O., Viana, A., Malikouski, R.G. \& Barros, B.L.A. 2018. Qualidade fisiológica de sementes de aroeira em função da maturação dos frutos sob diferentes temperaturas de germinação. Nucleus 15: 575-582.

Weller, S.L., Florentine, S.K. \& Chauhan, B.S. 2019. Influence of selected environmental factors on seed germination and seedling emergence of Dinebra panicea var. brachiata (Steud.). Crop Protection 117: 121-127.

Ye, N., Li, H., Zhu, G., Liu, Y., Liu, R., Xu, W., Jing Y., Peng X. \& Zhang, J. 2014. Copper suppresses abscisic acid catabolism and catalase activity, and inhibits seed germination of rice. Plant and Cell Physiology 55: 20082016.

You, R., Domínguez, C., Matamoros, V., Bayona, J.M. \& Díez, S. 2019. Chemical characterization and phytotoxicity assessment of peri-urban soils using seed germination and root elongation tests. Environmental Science and Pollution Research 26: 34401-34411.

Zafar, N., Iqbal, M. Z., Shafiq, M. \& Kabir, M. 2019. Effects of exhaust pollutants and garden soil on seed germination and seedling growth of maize (Zea mays L.) and sunflower (Helianthus annuus L.). Asian Journal of Research in Crop Science 4: 1-7.

Zhi, Y., Deng, Z., Luo, M., Ding, W., Hu, Y., Deng, J., Li, Y., Zhao, Y., Zhang, X., Wu, W. \& Huang, B. 2015. Influence of heavy metals on seed germination and early seedling growth in Eruca sativa Mill. American Journal of Plant Sciences 6: 582.

Zhu, Y., Xu, J., Lu, T., Zhang, M., Ke, M., Fu, Z., Pan, X. \& Qian, H. 2017. A comparison of the effects of copper nanoparticles and copper sulfate on Phaeodactylum tricornutum physiology and transcription. Environmental Toxicology and Pharmacology 56: 43-49. 